\title{
Population Consumption of Fish and Invertebrate Prey by Striped Bass (Morone saxatilis) from Coastal Waters of Northern Massachusetts, USA
}

\author{
Gary A. Nelson, Bradford C. Chase, and Jason D. Stockwell ${ }^{1}$ \\ Massachusetts Division of Marine Fisheries \\ Annisquam River Marine Fisheries Station \\ 30 Emerson Avenue, Gloucester, MA 01930, USA
}

\begin{abstract}
Nelson, G. A., B. C. Chase, and J. D. Stockwell. 2006. Population consumption of fish and invertebrate prey by striped bass (Morone saxatilis) from coastal waters of Northern Massachusetts, USA. J. Northw. Atl. Fish. Sci., 36: 111-126. doi: 10.2960/J.v36.m576
\end{abstract}

\begin{abstract}
Seasonal, age-class, and population-level changes in diet and consumption demand of prey by striped bass residing in coastal waters of northern Massachusetts were investigated to determine their potential predatory impact on ecologically- and economically-important prey species. Most consumption by individual striped bass of ages 3-8 came from crustaceans and fish. More crustaceans (50-78\% of total consumption) than fish were consumed during June-July, while more fish (52-88\% of total consumption) than crustaceans were consumed during August-September. Rock crabs Cancer irroratus and American lobsters Homarus americanus became more important to the production of striped bass as bass aged, but Atlantic menhaden Brevoortia tyrannus became less important. Together, the biomass of prey consumed by all age-classes in 2000 totaled over $5575 \mathrm{t}$. Atlantic menhaden accounted for $29 \%$ of the total biomass consumed, followed by rock crabs (18\%), American lobster (11\%), and Atlantic herring Clupea harengus (3\%). On a numerical basis, striped bass consumed seasonally over 3, 1940 , and 965 times the numbers of lobsters, rock crabs, and menhaden, respectively, taken annually by regional and statewide fisheries, suggesting striped bass may exert considerable predation pressure on these prey populations.
\end{abstract}

Key words: Morone saxatilis, predation, prey consumption

\section{Introduction}

The striped bass Morone saxatilis is a recreationally- and commercially-important anadromous fish species found along the United States Atlantic coast from Florida to Maine (Setzler et al., 1980). As a result of over-exploitation of the adult spawning stock, striped bass abundance reached alarmingly low levels in the early 1980s which prompted interstate management regulations that severely restricted fishing (Richards and Rago, 1999). After several years of stringent regulations, the Atlantic States Marine Fisheries Commission declared in 1995 that the Atlantic coast striped bass population had recovered (Field 1997; Richards and Rago 1999). Estimated stock abundance had increased from 5 million in 1982 to around 50 million by the mid-1990s (Anon., 2004).

Despite this remarkable recovery, there is concern over the health of the striped bass population, and their predatory impacts on key prey species. In the north- eastern United States, the angling public has expressed concern that the weight of large fish has decreased over the last two decades (Peros, 1999), suggesting that the striped bass population may be experiencing food limitation. Given that some important prey species of striped bass (e.g. young-of-the-year Atlantic menhaden Brevoortia tyrannus are declining (Anon., 2003), such limitation may be a plausible hypothesis. If food is limited for striped bass, they may exert high predation pressure on prey species that are of economical and cultural interest to humans. Thus, recovered striped bass may be in direct and significant competition with humans for potentially limited resources.

In Massachusetts waters, predation impact of striped bass may be substantial. With recent recreational striped bass catches being the largest observed in any coastal Atlantic state (Anon., 2004), a large proportion of the Atlantic population is believed to temporarily reside in Massachusetts waters during summer. While in Massachusetts waters, striped bass eat fish (e.g. sand

\footnotetext{
${ }^{1}$ Present Address: United States Geological Survey, Great Lakes Science Center, Lake Superior Biological Station, 2800 Lake Shore Drive East, Ashland, WI 54806, USA
} 
lance Ammodytes sp., Atlantic herring Clupea harengus and Atlantic menhaden) that are important to other fishes, marine mammals, seabirds, and humans (Bowman and Michaels, 1981; Powers and Brown, 1987; Chase, 2002; Nelson et al., 2003). They also eat the decapod crustacean American lobster Homarus americanus which supports a multi-million dollar commercial fishery in Massachusetts (Estrella and McKiernan, 1989; Nelson et al., 2003).

Given the record high levels of striped bass abundance, it is possible that striped bass are exerting considerable predation pressure on prey populations important to both the local ecosystem and to the economy of Massachusetts. However, there are no estimates of prey consumption by the striped bass population. This current study was conducted to develop estimates of total biomass and numbers of prey consumed by striped bass and to describe seasonal and age-class changes in diet and consumption demand during their summer residence.

\section{Materials and Methods}

\section{Individual Cumulative Consumption}

The algorithms of Fish Bioenergetics 3.0 (Hanson et al., 1997) were used to estimate individual consumption of prey ( $\mathrm{g} / \mathrm{fish} /$ day) by striped bass inhabiting nearshore (estuarine and rocky shoreline) waters of the northern Massachusetts (Fig. 1; Nelson et al., 2003). The algorithms were programmed in SAS (SAS Institute, 2000) to duplicate the bioenergetics model (BEM) for striped bass. The bioenergetics model is based on a balanced energetics equation (Kitchell et al., 1977). It estimates daily consumption of prey given species- and agespecific physiological parameters relating fish body size and temperature to metabolic costs, temperature in the environment occupied by the fish, the energy densities of predator and prey, the diet proportions of each prey species, and growth of the predator (Hanson et al., 1997). All physiological equations and parameters for striped bass required by the BEMs were taken from Hartman and Brandt (1995a). An oxycalorific value of 13.6 joules per $\mathrm{mg} \mathrm{O}_{2}$ consumed (Priede, 1985) was used to convert respiration values to joule energy equivalents.

Based on the results of Nelson et al. (2003), daily consumption rates were estimated for individual striped bass of ages 3-8 during two time periods: 1 June31 July (days 152-212 from 1 January) and 1 August30 September (days 213-273). For each age and time period, consumption was estimated on a daily time step. Daily water temperature came from a calibrated data logger stationed in Beverly Harbor, MA at an average depth of 8 m during 1997-2000 (Fig. 2). We considered these temperatures to be representative of the nearshore thermal environment experienced by striped bass. Energy densities (joules per gram of wet weight) of striped bass and their prey (Table 1) were obtained from Thayer et al. (1973) and Steimle and Terranova (1985), or were estimated from generic models of fish energy densities (Hartman and Brandt, 1995b) using seasonal means of percent dry weight derived in this study.

Food habits data from Nelson et al. (2003) were used to estimate prey diet proportions for each age of striped bass. Diet weights were reconstructed by using various length (total, fork, standard, and backbone length (mm) for fish; carapace width for crabs; carapace length for lobsters) and weight (g) relationships derived in this study, by Wigley et al. (2003), and by Ferry (2003). It was assumed that the diet proportions represented what an "average bass" from each age-class would eat on a daily basis throughout each time period. Only stomachs with prey were used in the calculation of prey proportions (Table 1).

Growth was estimated from weight (g) and age data of individuals collected by Nelson et al. (2003). Age, designated with a decimal extension reflecting the date of capture in days from 1 January, was determined from scale impressions by an experienced scale reader for striped bass. Due to small sample sizes in some months, mean weight-at-age at the beginning and end of each time period was estimated from a power regression model that appropriately characterized the relationship between weight $(w)$ and age $(A)$ for ages 2-10 (asymptotic standard errors are in parentheses):

$$
w=57.36(2.63) * A^{2.11(0.02)} ; \quad\left[r^{2}=0.83, n=3113\right]
$$

The cumulative consumption of prey by an individual striped bass during a time period was calculated by summing daily consumption rates over the number of days modelled in each BEM. We calculated cumulative consumption for all prey combined, five major taxa groups, and four prey species (American lobster, rock crab Cancer irroratus, Atlantic herring, and menhaden) deemed ecologically-important to striped bass or economically-important to Massachusetts.

Measures of uncertainty for consumption estimates were derived using a mixture of bootstrap (Efron and Tibshirani, 1998) and Monte Carlo (Haddon, 2001) resampling methods. Incorporated sources were errors in 1) diet proportions, 2) starting and ending weightsat-age, 3) parameters $C A$ and $C B$ of maximum consumption equation ( $C_{\max }$ in Hartman and Brandt, 1995a), and 4) parameters $R A, R B, R Q$, and $A C T$ of the metabolism equation ( $R$ in Hartman and Brandt, 1995a). 


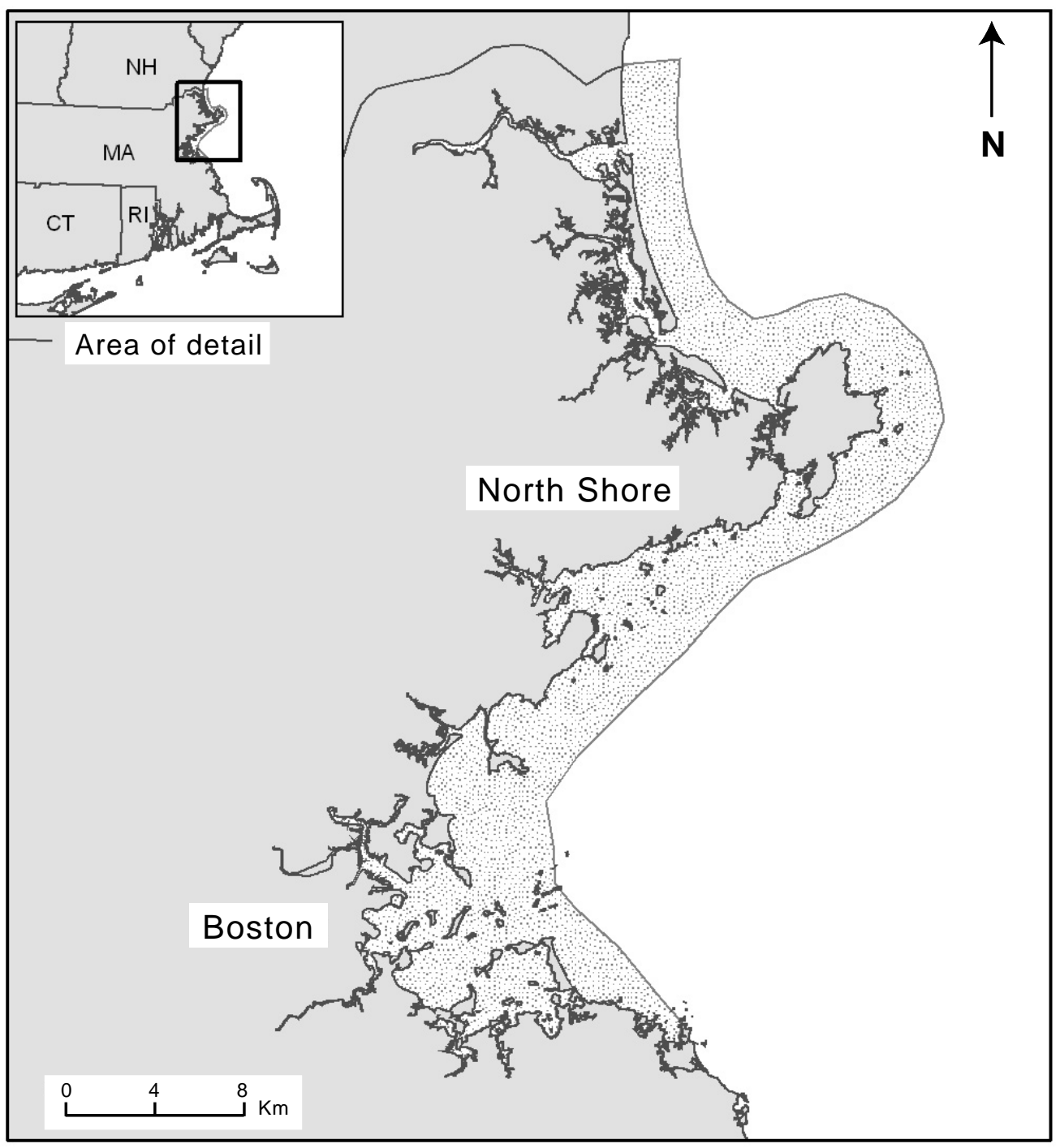

Fig. 1. Map showing boundaries of the North Shore region of Massachusetts.

Bootstrapping was used to resample diet data, while Monte Carlo sampling was used to randomly pick parameters for the maximum consumption, metabolism, and growth equations from normal distributions characterized with the original parameter estimates and associated standard errors. Standard errors were calculated from 95\% confidence intervals and sample sizes given in Table 1 and figures of Hartman and Brandt (1995a). A run for each age and time period consisted of calculating the new diet proportions from a bootstrap sample, substituting the new physiological and growth parameters into the appropriate equations, and then estimating daily consumption. For each period and age combination, 1000 runs were made and the mean and standard error of cumulative consumption $(q)$ were calculated from all runs. As a comparison to Hartman and Brandt (1995c), seasonal growth conversion efficiency for each age was calculated by dividing cumulative growth by the total consumption over the two periods.

\section{Age-class and Population Consumption}

The seasonal consumption of prey consumed by age-class and the entire population (ages 3-8) was calculated from estimates of average abundance of striped bass and cumulative individual consumption during the two time periods as follows:

$$
\hat{Q}_{a, i}=\sum_{j} \hat{\bar{N}}_{a, j} \cdot \hat{q}_{a, i, j}
$$

where $\hat{Q}_{a, i}$ is the total biomass (g) of prey $i$ consumed by age-class $a, \hat{\bar{N}}_{a, j}$ is the average abundance of age $a$ 


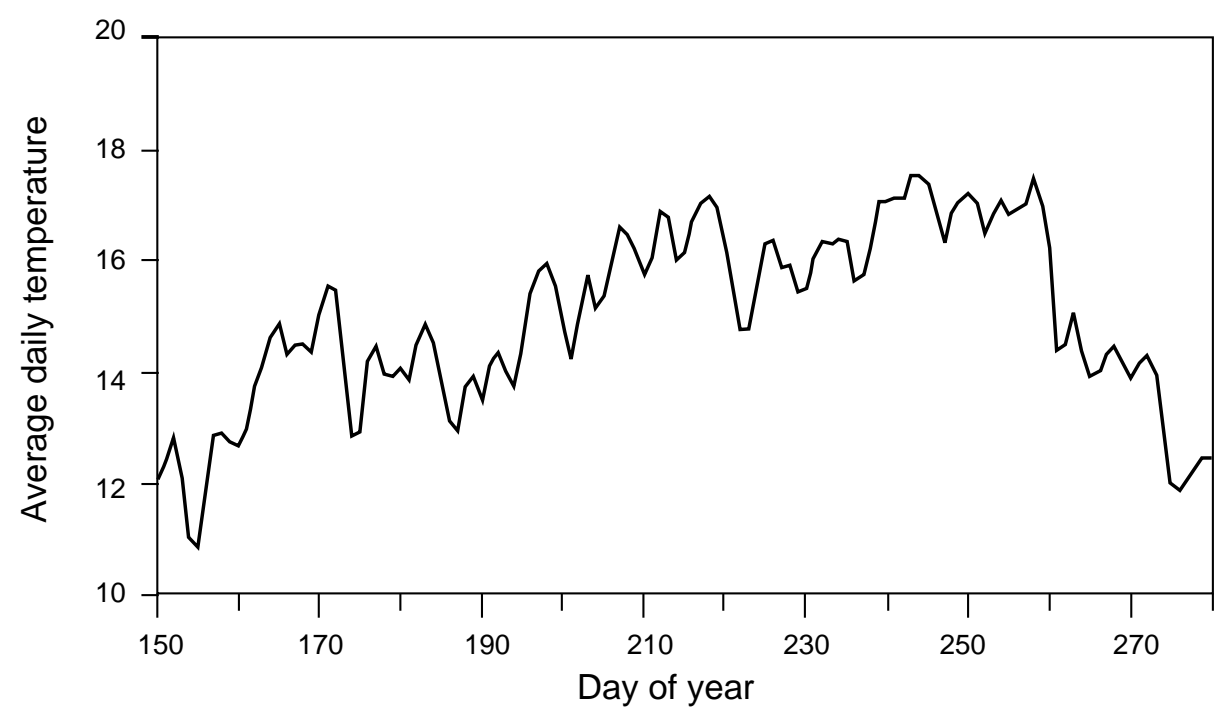

Fig. 2. Average daily water temperatures used in the bioenergetics models. Data were collected using a calibrated temperature data-logger during 1997-2000 at a depth of $8 \mathrm{~m}$ in Beverly Harbor, MA.

striped bass during period $j$, and $q_{a, i, j}$ is the cumulative individual consumption $(\mathrm{g} / \mathrm{fish})$ of prey $i$ during period $j$ by age $a$ striped bass. The variance $\left(S E^{2}\right)$ of $\hat{Q}_{a, i}$ was estimated from the product of two independent, random variables (Mood et al., 1974):

$$
\begin{aligned}
& S E^{2}\left(\hat{Q}_{a, i}\right)=\sum_{j} \hat{q}_{a, i, j}^{2} \cdot S E^{2}\left(\hat{\bar{N}}_{a, j}\right)+ \\
& \hat{\bar{N}}_{a, j}^{2} \cdot S E^{2}\left(\hat{q}_{a, i, j}\right)+S E^{2}\left(\hat{\bar{N}}_{a, j}\right) S E^{2}\left(\hat{q}_{a, i, j}\right)
\end{aligned}
$$

$\hat{\bar{N}}_{a, j}$ was calculated from a combined form of the exponential cohort survival model and Baranov's catch equation (Ricker, 1975; Quinn and Deriso, 1999):

$$
\hat{\bar{N}}_{a, j}=\frac{1-e^{-Z_{j}}}{Z_{j}} \cdot \frac{\hat{L}_{a}}{\mu_{a}} \cdot e^{-p_{t-1} \cdot M-\theta_{t-1} \cdot F_{a}}
$$

where $L_{a}$ is the number of age $a$ fish killed annually, $\mu_{a}$ is the annual exploitation rate of age $a, t$ is the beginning month of period $j, \rho_{t-1}$ and $\theta_{t-1}$ are the fractions of natural $(M)$ and fishing $(F)$ mortality, respectively, experienced by age $a$ through month $t-1$, and $Z_{j}$ is the total instantaneous mortality rate during period $j$. This model estimates the hypothetical numbers-at-age that had to be present at 1 January, even though striped bass are not present in Massachusetts waters during this time, given $L_{a}, M$, and $F_{a}$, and then decrements those numbers over time given bi-monthly estimates of $F$ and $Z$. A full $F$ was derived by subtracting $M$ for the coastwide stock (0.15) (Anon., 2004) from an estimate of $Z(0.50)$ derived us- ing total catch-at-age (Nelson et al., 2001) and the Chapman-Robson survival estimator (Chapman and Robson, 1960). Full $F$ was then apportioned to each age using the partial recruitment vector calculated for the coastal migratory population of striped bass in 2000 (Anon., 2004). F-at-age was then distributed equally across May-October, the months when striped bass fisheries in Massachusetts occur; therefore, $\theta_{t-1}$ was 0 for $t \leq 5$, $(t-5) / 6$ for $6 \leq t \leq 11$, and 1 otherwise. We distributed natural mortality equally across all months so that $\rho_{t-1}$ was calculated as $(t-1) / 12$. Assuming constant mortality rates for each age, an estimator for the variance of $\hat{\bar{N}}_{a, j}$ is

$$
S^{2}\left(\hat{\bar{N}}_{a, j}\right)=\left(\frac{1-e^{-Z_{j}}}{Z_{j}} \frac{e^{-p_{t-1} M-\theta_{t-1} F_{a}}}{\mu_{a}}\right)^{2} S E^{2}\left(\hat{L}_{a}\right)
$$

To estimate $L_{a}$ for each age, we first post-stratified the National Marine Fisheries Service's Marine Recreational Fisheries Statistics Survey (MRFSS) estimates for Massachusetts by two-month wave, county and fishing mode (i.e. shore versus boat fishing). The harvest and release estimates from Essex, Suffolk, and Norfolk counties for anglers fishing in estuaries (all modes) and those fishing in the ocean from shore were selected as representing the numbers harvested and released for the nearshore region of northern Massachusetts. The MRFSS estimates were then summed across all waves to get annual harvest $(\hat{C})$ and releases $(\hat{E})$. We then apportioned the MRFSS numbers into age-classes by using estimates of proportions-at-age. The proportion of age $a$ that was 
TABLE 1. Energy densities of prey and predator (joules per gram wet weight), reconstructed diet composition (percent biomass), total number of stomachs, number of stomachs with prey, average stomach weight (g), and average body weight (g) of striped bass during June-July (JJ: days 152-212) and August-September (AS: days 213-273).

\begin{tabular}{|c|c|c|c|c|c|c|c|c|c|c|c|c|c|c|}
\hline \multirow[b]{2}{*}{ Category } & \multicolumn{2}{|c|}{ Energy Density } & \multicolumn{2}{|c|}{ Age 3} & \multicolumn{2}{|c|}{ Age 4} & \multicolumn{2}{|c|}{$\begin{array}{c}\text { Percent Biomass } \\
\text { Age } 5\end{array}$} & \multicolumn{2}{|c|}{ Age 6} & \multicolumn{2}{|c|}{ Age 7} & \multicolumn{2}{|c|}{ Age 8} \\
\hline & $\mathrm{JJ}$ & AS & $\mathrm{JJ}$ & AS & $\mathrm{JJ}$ & AS & JJ & AS & JJ & AS & JJ & AS & JJ & AS \\
\hline \multicolumn{15}{|l|}{ Prey } \\
\hline Polychaetes $^{\mathrm{a}}$ & 4200 & 4200 & 8.8 & 0.3 & 2.4 & 0.2 & 1.3 & - & 0.7 & 0.3 & - & - & 0.3 & - \\
\hline Molluscs $^{\mathrm{a}}$ & 5283 & 5283 & $<0.1$ & 0.2 & 5.0 & 4.5 & 1.1 & 0.9 & 0.8 & 0.1 & 3.0 & $<0.1$ & $<0.1$ & 2.2 \\
\hline Sand shrimp ${ }^{\mathrm{b}}$ & 3700 & 3700 & 9.5 & 0.3 & 1.5 & 0.5 & $<0.1$ & 0.3 & 0.2 & 0.2 & 0.3 & - & $<0.1$ & - \\
\hline American lobster ${ }^{\mathrm{b}}$ & 4800 & 4800 & 0.1 & 0.3 & 12.3 & 2.0 & 12.6 & 2.0 & 4.4 & 2.1 & 27.7 & 17.2 & 51.2 & 17.4 \\
\hline Rock crab ${ }^{\mathrm{b}}$ & 3700 & 3700 & 10.7 & 7.2 & 29.2 & 8.4 & 35.5 & 9.7 & 22.8 & 7.8 & 16.5 & 7.3 & 5.3 & 44.4 \\
\hline Green crab ${ }^{c}$ & 3700 & 3700 & 5.2 & 1.8 & 7.8 & 0.8 & 5.5 & 0.9 & 2.8 & 2.2 & 3.4 & 6.8 & - & 5.1 \\
\hline Mysids $^{\mathrm{d}}$ & 5265 & 5265 & 0.5 & $<0.1$ & 1.0 & 0.1 & 0.3 & - & 0.1 & - & - & - & $<0.1$ & - \\
\hline Isopods $^{\mathrm{d}}$ & 3400 & 3400 & - & - & - & - & $<0.1$ & - & - & - & - & - & - & - \\
\hline Amphipods $^{\mathrm{a}}$ & 3400 & 3400 & 10.5 & 0.8 & 6.8 & 0.1 & 1.3 & 0.3 & 0.3 & - & $<0.1$ & 0.2 & - & - \\
\hline \multicolumn{15}{|l|}{ Other small } \\
\hline crustacea $^{\mathrm{e}}$ & 6038 & 6038 & - & - & - & - & $<0.1$ & - & $<0.1$ & - & - & 0.4 & - & - \\
\hline \multicolumn{15}{|l|}{ Other large } \\
\hline crustacea $^{\mathrm{e}}$ & 4169 & 4169 & 1.1 & - & 9.8 & 1.7 & 9.0 & 5.0 & 5.0 & 3.4 & - & 6.5 & 2.9 & 18.4 \\
\hline \multicolumn{15}{|l|}{ Unidentifiable } \\
\hline Misc. invertebraes ${ }^{\mathrm{e}}$ & 3203 & 3203 & 0.2 & - & - & - & 0.9 & $<0.1$ & - & - & 0.4 & 0.8 & 1.0 & - \\
\hline \multicolumn{15}{|l|}{ Blueback/Alewife } \\
\hline herring $^{f}$ & 5817 & 5412 & 10.3 & - & 0.5 & - & $<0.1$ & - & 7.3 & - & 0.6 & - & - & - \\
\hline Menhaden $^{f}$ & 4038 & 4038 & - & 81.7 & - & 73.0 & $<0.1$ & 73.7 & - & 55.0 & - & 31.9 & - & - \\
\hline Atlantic herring ${ }^{\mathrm{f}}$ & 8188 & 6010 & 30.8 & - & 2.9 & - & $<0.1$ & - & 8.2 & - & 8.5 & - & 14.5 & 0.6 \\
\hline \multicolumn{15}{|l|}{ Unidentifiable } \\
\hline herring $^{\mathrm{a}}$ & 7540 & 7540 & - & - & - & - & 0.2 & - & - & - & - & - & - & - \\
\hline Atlantic silverside ${ }^{\mathrm{b}}$ & 7300 & 7300 & - & 0.6 & 1.1 & 0.4 & $<0.1$ & 0.1 & - & - & - & - & - & - \\
\hline Rock gunnel $^{\mathrm{a}}$ & 5058 & 5058 & 3.4 & - & 5.0 & 1.7 & 5.6 & 0.4 & 0.7 & 2.3 & 0.1 & 2.6 & 0.7 & - \\
\hline Sand lance ${ }^{f}$ & 6896 & 6270 & 2.4 & 1.5 & 1.2 & 0.3 & 0.5 & - & - & - & 0.7 & - & 0.4 & - \\
\hline Other fish ${ }^{\mathrm{a}}$ & 5168 & 5170 & 3.8 & 4.4 & 3.4 & 4.5 & 18.3 & 5.4 & 35.3 & 18.3 & 36.5 & 20.5 & 22.8 & 8.5 \\
\hline \multicolumn{15}{|l|}{ Predator } \\
\hline Striped bass ${ }^{\mathrm{f}}$ & 6395 & 6395 & & & & & & & & & & & & \\
\hline Total stomachs & & & 85 & 115 & 167 & 214 & 96 & 120 & 106 & 110 & 102 & 78 & 56 & 53 \\
\hline Stomachs with prey & & & 70 & 70 & 112 & 140 & 65 & 70 & 56 & 57 & 40 & 40 & 31 & 17 \\
\hline \multicolumn{15}{|l|}{ Ave. stomach } \\
\hline weight(g) & & & 6.2 & 9.8 & 7.4 & 14.9 & 13.0 & 17.9 & 10.1 & 12.6 & 13.6 & 14.5 & 31.7 & 12.2 \\
\hline $\mathrm{SE}_{\text {stomach weight }}$ & & & 0.95 & 1.61 & 1.08 & 1.75 & 2.00 & 2.87 & 2.19 & 2.18 & 3.26 & 3.52 & 7.61 & 4.69 \\
\hline Ave. bass weight (g) & & & 946 & 999 & 1417 & 1472 & 2093 & 1992 & 2873 & 2977 & 4157 & 4290 & 5135 & 4948 \\
\hline $\mathrm{SE}_{\text {bass weight }}$ & & & 33.4 & 25.4 & 34.2 & 27.4 & 69.9 & 66.6 & 115.2 & 97.8 & 110.9 & 154.4 & 180.3 & 221.1 \\
\hline
\end{tabular}

${ }^{a}$ average taxa values in Steimle and Terranova (1985).

b Steimle and Terranova (1985).

c energy density of rock crab.

d Euphausidacea in Steimle and Terranova (1985).

e average taxa values in Steimle and Terranova (1985) and Thayer et al. (1973).

${ }^{f}$ derived from generic models of fish energy density (Hartman and Brandt, 1995b) and seasonal means of percent dry weight (this study). 
harvested or released and its variance was estimated from length frequency and age-length keys developed for striped bass from Massachusetts waters using a twostage random sampling estimator (Quinn and Deriso, 1999, pp. 303-306):

$$
\hat{p}_{a}=\sum_{k=1}^{m} \hat{a}_{k} \cdot \hat{p}_{k, a}
$$

with

$$
S E^{2}\left(\hat{p}_{a}\right)=\sum_{k=1}^{m} \frac{\hat{a}_{k}^{2} \cdot \hat{p}_{k, a} \cdot\left(1-\hat{p}_{k, a}\right)}{A_{k}-1}+\sum_{k=1}^{m} \frac{\hat{a}_{k} \cdot\left(\hat{p}_{k, a}-\hat{p}_{a}\right)}{T}
$$

where $m$ is the total number of length intervals, $\hat{a}_{k}$ is the estimated proportion of lengths in interval $k, \hat{p}_{k, a}$ is the proportion of age $a$ in interval $k, A_{k}$ is the total number of age samples in interval $k$, and $T$ is the total number of length samples. The total number of harvested fish of age $a\left(\hat{C}_{a}\right)$ was calculated as

$$
C_{a}=\hat{C} \cdot \hat{p}_{c, a}
$$

The variance estimate of $\hat{C}_{a}$ was derived as

$$
\begin{aligned}
& S E^{2}\left(\hat{C}_{a}\right)=\hat{p}_{c, a}^{2} \cdot S E^{2}(\hat{C})+\hat{C}^{2} \cdot S E^{2}\left(\hat{p}_{c, a}\right) \\
& +S E^{2}(\hat{C}) \cdot S E^{2}\left(\hat{p}_{c, a}\right)
\end{aligned}
$$

Similarly, the total number of bass of age $a$ that died due to hooking and handling stress $\left(\hat{H}_{a}\right)$ was derived as follows:

$$
\hat{H}_{a}=\hat{h} \cdot \hat{E} \cdot \hat{p}_{E, a}
$$

where $\hat{h}$ is the proportion of released bass that die (Diodati and Richards, 1996), $\hat{E}$ is the number of released fish, and $\hat{p}_{E, a}$ is the proportion of age $a$ in the releases. Its variance is given by:

$$
\begin{aligned}
& S E^{2}\left(\hat{H}_{a}\right)=S E^{2}(\hat{h}) \cdot \hat{E}^{2} \cdot \hat{p}_{E, a}^{2}+\hat{h}^{2} \cdot \hat{p}_{E, a}^{2} \cdot S E^{2}(\hat{E})+ \\
& \hat{h}^{2} \cdot \hat{E}^{2} \cdot S E^{2}\left(\hat{p}_{E, a}\right)+\hat{h}^{2} \cdot S E^{2}(\hat{E}) \cdot S E^{2}\left(\hat{p}_{E, a}\right)+ \\
& \hat{p}_{E, a}^{2} \cdot S E^{2}(\hat{h}) \cdot S E^{2}(\hat{E})+E^{2} \cdot S E^{2}(\hat{h}) \cdot S E^{2}\left(\hat{p}_{E, a}\right)+ \\
& S E^{2}(\hat{E}) \cdot S E^{2}\left(\hat{p}_{E, a}\right) \cdot S E^{2}(\hat{h})
\end{aligned}
$$

Finally, $\hat{L}_{a}$ was estimated as:

$$
\hat{L}_{a}=\hat{C}_{a}+\hat{H}_{a}
$$

with

$$
S E^{2}\left(\hat{L}_{a}\right)=S E^{2}\left(\hat{C}_{a}\right)+S E^{2}\left(\hat{H}_{a}\right)
$$

We used the MRFSS harvest and release numbers, length-frequency, and age data for striped bass collected in Massachusetts during 2000, a representative year during the 1997-2000 diet study, to calculate abundance for each age class. Estimates of harvested and released fish by commercial striped bass anglers were not included in the analyses because fishing generally occurs in more offshore waters, harvested fish are generally outside the age range studied here (>age 8 ), and commercial discards represent only a small fraction $(<2 \%)$ of what dies after release in the recreational fishery. Recreational harvest and release numbers from boats fishing in waters other than estuaries were not included because no justifiable means of partitioning the numbers into nearshore and offshore strata were available.

The total number of prey consumed by an age class was estimated by

$$
\hat{P}_{a i}=\frac{\hat{Q}_{a, i}}{\hat{\bar{w}}_{a, i}}
$$

where $\hat{P}_{a, i}$ is the total number of prey $i$ consumed by age-class $a, \hat{Q}_{a, i}$ is the total biomass consumed, and $\hat{\bar{w}}_{a, i}$ is the average back-calculated weight of individuals of prey $i$ found in the stomachs of striped bass. The variance of $\hat{P}_{a, i}$ is given by:

$$
S E^{2}\left(\hat{P}_{a, i}\right)=\hat{P}_{a, i}^{2} \cdot\left(\frac{S E^{2}\left(\hat{Q}_{a, i}\right)}{\hat{Q}_{a, i}^{2}}+\frac{S E^{2}\left(\hat{\bar{w}}_{a, i}\right)}{\hat{\bar{w}}_{a, i}^{2}}\right)
$$

assuming negligible covariance (Mood et al., 1974). The total biomass and numbers of prey consumed by the population of striped bass and their variances were calculated by summing total age-class consumption and variances over all ages.

Total biomass and numbers consumed by all ageclasses were compared to the commercial landings of American lobster, rock crab, Atlantic herring and Atlantic menhaden from northern Massachusetts, when data could be partitioned into regions, or from the entire state in order to examine the gross magnitude of striped bass predation in relation to human harvesting. Landings data were collected by the Massachusetts Division of Marine Fisheries and the National Marine Fisheries Service through various required dealer and/or fishermen reporting systems. Such comparisons may suggest potential impacts on ecologically- and economically-important prey as well as indirect impacts on humans.

\section{Results}

\section{Individual Cumulative Consumption}

Estimates of cumulative consumption of all prey ranged from 695 and $1134 \mathrm{~g} / \mathrm{fish}$ at age 3 to 3010 and 4 361g/fish at age 8 during June-July and AugustSeptember, respectively, and were generally higher dur- 
TABLE 2. Mean BEM cumulative consumption ( $q$ : g/fish), standard error (SE), and proportional standard error (PSE) of general prey taxa for ages 3-8 striped bass during June-July and August-September.

\begin{tabular}{|c|c|c|c|c|c|c|c|}
\hline \multirow[b]{2}{*}{ Age } & \multirow[b]{2}{*}{ Prey } & \multicolumn{3}{|c|}{ June-July } & \multicolumn{3}{|c|}{ Aug-Sept } \\
\hline & & $q$ & $S E$ & PSE & $q$ & $S E$ & PSE \\
\hline \multirow[t]{10}{*}{3} & All Prey & 695.4 & 93.33 & 0.13 & 1134.3 & 155.79 & 0.14 \\
\hline & Polychaetes & 62.3 & 34.24 & 0.55 & 3.0 & 1.48 & 0.49 \\
\hline & Molluscs & 0.1 & 0.04 & 0.40 & 2.7 & 1.34 & 0.50 \\
\hline & Crustaceans & 283.0 & 50.16 & 0.18 & 130.0 & 36.58 & 0.28 \\
\hline & Am. Lobster & 0.6 & 0.41 & 0.68 & 3.5 & 2.52 & 0.72 \\
\hline & Rock Crab & 73.2 & 18.38 & 0.25 & 83.2 & 25.22 & 0.30 \\
\hline & Fish & 348.5 & 56.76 & 0.16 & 998.6 & 140.48 & 0.14 \\
\hline & Atl. Herring & 210.7 & 44.20 & 0.21 & - & - & - \\
\hline & Menhaden & - & - & - & 924.4 & 133.60 & 0.14 \\
\hline & Other & 1.6 & 1.20 & 0.75 & 0.1 & 0.06 & 0.60 \\
\hline \multirow[t]{10}{*}{4} & All Prey & 1285.4 & 172.53 & 0.13 & 1641.5 & 243.58 & 0.15 \\
\hline & Polychaetes & 30.8 & 22.35 & 0.73 & 3.1 & 3.11 & 1.00 \\
\hline & Molluscs & 65.9 & 45.77 & 0.69 & 75.6 & 59.80 & 0.79 \\
\hline & Crustaceans & 1008.2 & 143.83 & 0.14 & 256.0 & 60.24 & 0.24 \\
\hline & Am. Lobster & 153.9 & 53.69 & 0.35 & 3.5 & 1.29 & 0.37 \\
\hline & Rock Crab & 376.7 & 70.11 & 0.19 & 139.5 & 34.62 & 0.25 \\
\hline & Fish & 180.6 & 37.64 & 0.21 & 1306.7 & 219.86 & 0.17 \\
\hline & Atl. Herring & 37.4 & 13.26 & 0.35 & - & - & - \\
\hline & Menhaden & - & - & - & 1194.7 & 206.00 & 0.17 \\
\hline & Other & - & - & - & - & - & - \\
\hline \multirow[t]{10}{*}{5} & All Prey & 1827.9 & 270.99 & 0.15 & 2259.9 & 341.69 & 0.15 \\
\hline & Polychaetes & 23.4 & 14.65 & 0.63 & 0.1 & 0.13 & 1.30 \\
\hline & Molluscs & 18.6 & 16.51 & 0.89 & 27.4 & 36.47 & 1.33 \\
\hline & Crustaceans & 1315.8 & 234.09 & 0.18 & 487.7 & 211.61 & 0.43 \\
\hline & Am. Lobster & 235.6 & 99.16 & 0.42 & 56.0 & 63.70 & 1.13 \\
\hline & Rock Crab & 647.5 & 151.27 & 0.23 & 245.6 & 178.72 & 1.14 \\
\hline & Fish & 454.2 & 115.82 & 0.25 & 1744.4 & 364.07 & 0.21 \\
\hline & Atl. Herring & - & - & - & - & - & - \\
\hline & Menhaden & - & - & - & 1603.9 & 368.58 & 0.23 \\
\hline & Other & 15.8 & 9.51 & 0.60 & 0.3 & 0.41 & 1.37 \\
\hline \multirow[t]{10}{*}{6} & All Prey & 2107.9 & 387.89 & 0.18 & 2783.1 & 456.81 & 0.16 \\
\hline & Polychaetes & 13.2 & 10.05 & 0.76 & 6.6 & 9.23 & 1.40 \\
\hline & Molluscs & 19.1 & 27.36 & 1.43 & 2.2 & 2.95 & 1.34 \\
\hline & Crustaceans & 1034.5 & 405.28 & 0.39 & 685.1 & 266.93 & 0.39 \\
\hline & Am. Lobster & 105.5 & 115.73 & 1.10 & 59.3 & 29.15 & 0.49 \\
\hline & Rock Crab & 511.2 & 265.37 & 0.52 & 219.3 & 133.54 & 0.61 \\
\hline & Fish & 1040.7 & 291.17 & 0.28 & 2089.2 & 417.39 & 0.20 \\
\hline & Atl. Herring & 144.7 & 194.40 & 1.34 & - & - & - \\
\hline & Menhaden & - & - & - & 1526.0 & 394.11 & 0.26 \\
\hline & Other & 0.2 & 0.26 & 1.30 & - & - & - \\
\hline \multirow[t]{10}{*}{7} & All Prey & 2590.8 & 472.50 & 0.18 & 3423.1 & 564.01 & 0.16 \\
\hline & Polychaetes & 0.2 & 0.25 & 1.25 & $<0.1$ & $<0.01$ & 1.10 \\
\hline & Molluscs & 99.2 & 144.07 & 1.45 & 0.4 & 0.59 & 1.48 \\
\hline & Crustaceans & 1438.7 & 678.11 & 0.47 & 1615.4 & 595.32 & 0.37 \\
\hline & Am. Lobster & 839.6 & 546.55 & 0.65 & 599.5 & 305.17 & 0.51 \\
\hline & Rock Crab & 443.1 & 180.69 & 0.41 & 302.8 & 283.63 & 0.94 \\
\hline & Fish & 1043.2 & 655.05 & 0.63 & 1768.8 & 645.09 & 0.36 \\
\hline & Atl. Herring & 209.5 & 290.40 & 1.39 & - & - & - \\
\hline & Menhaden & - & - & - & 1010.2 & 672.07 & 0.66 \\
\hline & Other & 9.6 & 13.34 & 1.39 & 38.5 & 63.44 & 1.65 \\
\hline
\end{tabular}


TABLE 2. (Cont'd). Mean BEM cumulative consumption ( $q$ : $g / f i s h)$, standard error (SE), and proportional standard error (PSE) of general prey taxa for ages 3-8 striped bass during June-July and August-September.

\begin{tabular}{|c|c|c|c|c|c|c|c|}
\hline \multirow[b]{2}{*}{ Age } & \multirow[b]{2}{*}{ Prey } & \multicolumn{3}{|c|}{ June-July } & \multicolumn{3}{|c|}{ Aug-Sept } \\
\hline & & $q$ & $S E$ & PSE & $q$ & $S E$ & PSE \\
\hline \multirow[t]{10}{*}{8} & All Prey & 3009.7 & 543.53 & 0.18 & 4361.1 & 725.53 & 0.17 \\
\hline & Polychaetes & 12.1 & 17.60 & 1.45 & $<0.1$ & $<0.01$ & 1.00 \\
\hline & Molluscs & 0.4 & 0.59 & 1.48 & 117.4 & 131.65 & 1.12 \\
\hline & Crustaceans & 1740.6 & 579.05 & 0.33 & 3843.7 & 733.46 & 0.19 \\
\hline & Am. Lobster & 1448.4 & 501.99 & 0.35 & 824.4 & 851.00 & 1.03 \\
\hline & Rock Crab & 166.4 & 96.19 & 0.58 & 1871.5 & 824.38 & 0.44 \\
\hline & Fish & 1222.9 & 505.31 & 0.41 & 399.9 & 321.69 & 0.80 \\
\hline & Atl. Herring & 360.5 & 297.75 & 0.83 & 37.6 & 48.42 & 1.29 \\
\hline & Menhaden & - & - & - & - & - & - \\
\hline & Other & 33.7 & 36.10 & 1.07 & - & - & - \\
\hline
\end{tabular}

ing the latter period (Table 2). Striped bass consumed mostly crustaceans and fish, but more crustaceans (50-78\% of total consumption) than fish were consumed by individuals of ages $4-8$ bass during JuneJuly, while more fish (52-88\% of total consumption) than crustaceans were consumed by individuals of ages 3-7 during August-September (Fig. 3). In addition, the percentage of crustaceans and fish consumed during August-September increased and declined, respectively, as striped bass age increased (Fig. 3). Cumulative consumption of polychaetes, molluscs, and "other" prey per individual was low $(<117 \mathrm{~g} /$ fish $)$ during both time periods (Table 2; Fig. 3). Growth conversion efficiency was 0.09 for age 3, 0.07 for ages $4-6$, and 0.06 for ages 7 and 8 striped bass.

Lobster consumption accounted for $<12 \%$ of total consumption by ages 3-6 striped bass during June-July and August-September, but $>17 \%$ of total consumption by ages 7 and 8 during both time periods (Table 2; Fig. 4). Consumption of rock crabs was generally highest during June-July, contributing up to 35\% of the total consumption (Fig. 4), peaked at age 5, and generally declined as age of bass increased (the exception being age 8 in August-September) (Table 2). Estimates of Atlantic herring consumption (most had low precision) represented $0-30 \%$ of total cumulative consumption for ages 3-8 striped bass during June-July, but it contributed little to total consumption in AugustSeptember (Table 2; Fig. 4). No menhaden were consumed in June-July, but they became the dominant prey in August-September, contributing 29-81\% of total consumption for ages 3-7 striped bass (Table 2; Fig. 4).

\section{Estimates of Abundance}

The total number of harvested $(\hat{C})$ and released $(\hat{E})$ striped bass estimated by the MRFSS in 2000 was 40267 and 3.5 million fish, respectively (Table 3). Agespecific estimates of harvest $\left(\hat{C}_{a}\right)$ ranged from 403 fish at age 5 to 8456 fish at age 8 , and estimates of bass that died due to handling and hooking $\left(\hat{H}_{a}\right)$ ranged from 16113 fish at age 3 to 93455 fish at age 4 (Table 3). Combined losses-at-age $\left(L_{a}\right)$ were highest at age 4 and declined as age increased (Table 4). Estimates of average abundance ranged from 88906 fish at age 8 to 544518 fish at age 4 during June-July, and from 77679 fish at age 8 to 500147 fish at age 4 during August-September (Table 4), indicating that about 1.3 million striped bass of ages 3-8 were present in nearshore waters of northern Massachusetts during summer of 2000. The large number of age 4 striped bass reflected the strong 1996 yearclass spawned in Chesapeake Bay (Anon., 2004).

\section{Age-class and Population Consumption}

Age-class consumption of all prey ranged from 369 (metric tons) at age 3 to $1521 \mathrm{t}$ at age 4, and peaked at ages 4 and 6 (Table 5). Highest consumption of polychaetes, molluscs, crustaceans and fish was imposed by age 4 bass, but secondary peaks in consumption of crustaceans and fish occurred at ages 7 and 6, respectively (Table 5). Age 4 striped bass consumed the most rock crabs and menhaden, ages 7 and 8 striped bass consumed the most lobsters, and age 3 striped bass consumed the most Atlantic herring (Table 6). Together, 


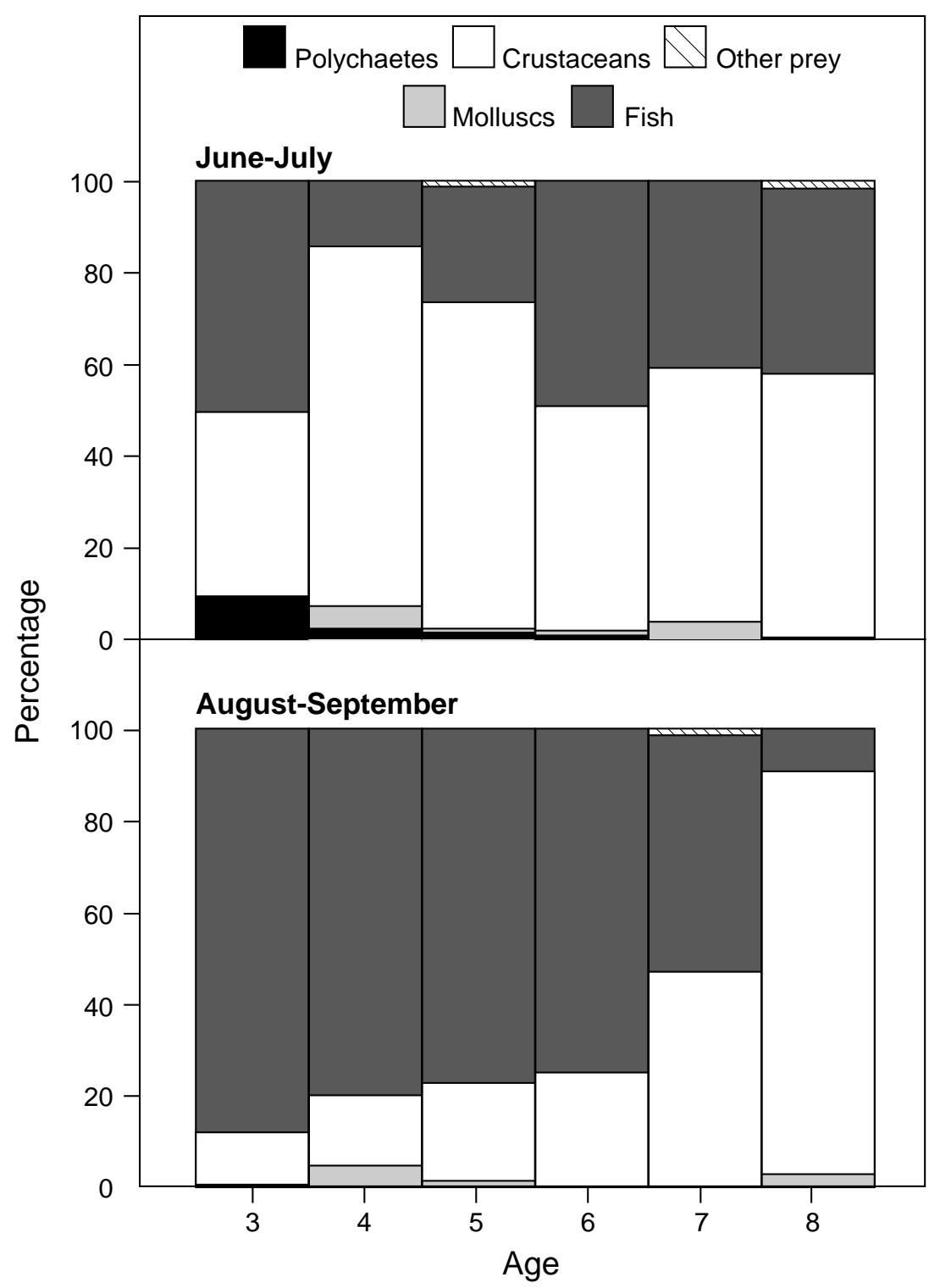

Fig. 3. General prey composition (percentage of total consumption (g)) of ages 3-8 striped bass during June-July and August-September in northern Massachusetts.

prey consumption by all ages totaled over 5575 t. Atlantic menhaden accounted for $29 \%$ of the total biomass consumed seasonally by ages 3-8 striped bass in 2000, followed by rock crabs (18\%), American lobster (11\%), and Atlantic herring (3\%).

The seasonal biomass consumption of lobsters by striped bass was much lower than the annual commercial landings of northern Massachusetts in 2000, while the consumption of rock crab was much higher (Table 7). Striped bass consumed more menhaden biomass, but less herring biomass, than were landed statewide (Table 7). On a numerical basis, however, striped bass consumed seasonally over 3, 1 940, and 965 times the numbers of lobsters, rock crabs, and menhaden, respectively, taken annually by regional and statewide fisheries due to the small sizes of prey eaten (Table 7).

\section{Discussion}

\section{Individual Cumulative Consumption}

We believe that the estimates of individual cumulative consumption produced by the BEMs are reasonably accurate for several reasons. First, the efficacy of this modeling approach has been corroborated for many fish 


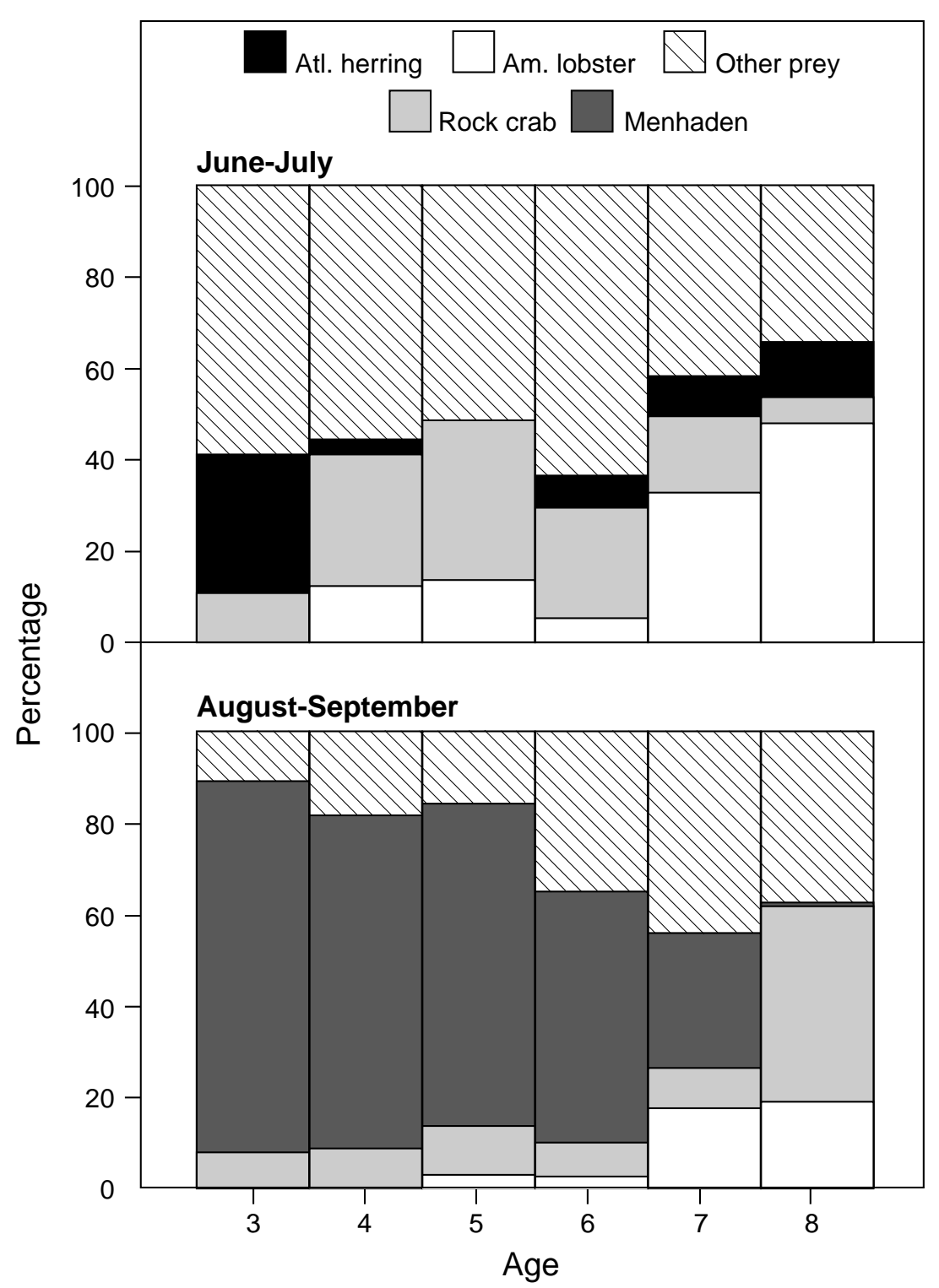

Fig. 4. Selected-prey composition (percentage of total consumption (g)) of ages 3-8 striped bass during June-July and August-September in northern Massachusetts.

species (e.g., Beauchamp et al., 1989; Huuskonen et al., 1998) including age 0 striped bass (Hartman and Brandt, 1993; Hartman, 2000a). Second, the model parameters for the consumption and respiration equations, the most important contributors to prediction errors (Bartell et al., 1986), were well-estimated by Hartman and Brandt (1995a). Lastly, the diet data reflected average composition over each period (Nelson et al., 2003) and therefore assuming it reflected the daily composition is not unreasonable. Similarly, the exponential model should give accurate predictions of average growth given that the sample size was large, and declines in growth during warm months were not expected because water temperatures in northern Massachusetts never approach critical temperatures $\left(>30^{\circ} \mathrm{C}\right.$ ) (DMF daily temperature records from 1997-2005).

Our results showed that the contribution of specific prey to the production of striped bass varied over time. Most consumption came from benthic crustaceans during June and July, and from pelagic fish during AugustSeptember. Rock crabs and lobsters became more 


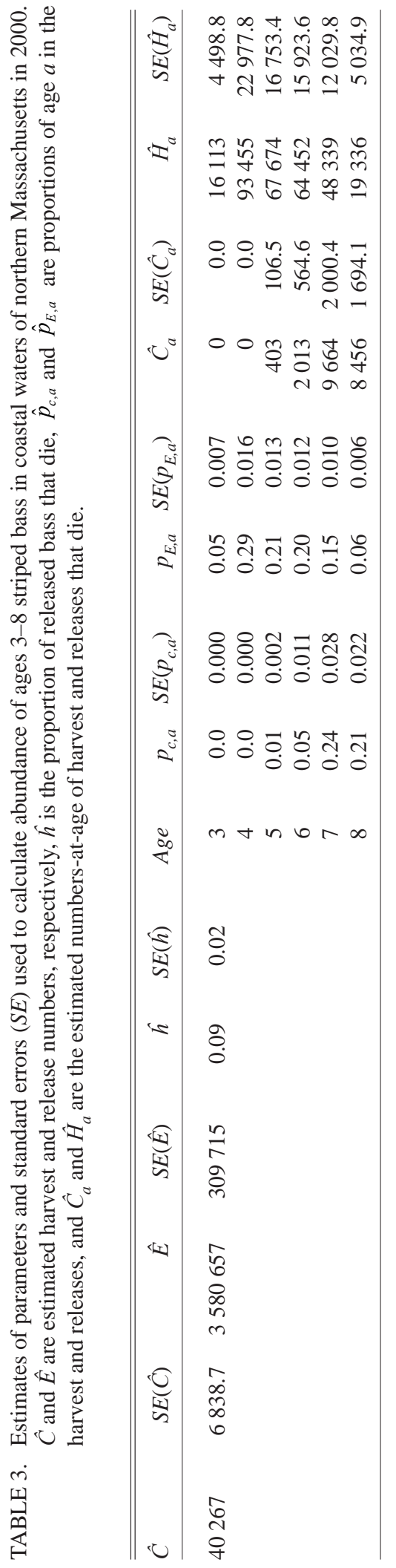


TABLE 4. Estimates of annual losses $(L)$ and average abundance $(N)$ during the June-July and August-September periods in 2000 for ages 3-8 striped bass in coastal waters of northern Massachusetts. Parameters are defined in the text.

\begin{tabular}{|c|c|c|c|c|c|c|c|c|c|c|c|c|c|}
\hline \multirow[b]{2}{*}{ Age } & \multirow[b]{2}{*}{$L_{a}$} & \multirow[b]{2}{*}{$\operatorname{SE}\left(L_{a}\right)$} & \multirow[b]{2}{*}{$\mu_{a}$} & \multirow[b]{2}{*}{$F_{a}$} & \multirow[b]{2}{*}{$Z_{j}$} & \multicolumn{4}{|c|}{ June-July } & \multicolumn{4}{|c|}{ August-September } \\
\hline & & & & & & $\rho$ & $\theta$ & $\hat{\bar{N}}_{a}$ & $\operatorname{SE}\left(\hat{\bar{N}}_{a}\right)$ & $\rho$ & $\theta$ & $\hat{\bar{N}}_{a}$ & $\operatorname{SE}\left(\hat{\bar{N}}_{a}\right)$ \\
\hline 3 & 16113 & 4498.8 & 0.07 & 0.08 & 0.052 & 0.417 & 0.167 & 207957 & 58062.2 & 0.583 & 0.500 & 197485 & 55138.5 \\
\hline 4 & 93455 & 22977.8 & 0.15 & 0.18 & 0.085 & 0.417 & 0.167 & 544518 & 133880.8 & 0.583 & 0.500 & 500147 & 122971.1 \\
\hline 5 & 68077 & 16753.7 & 0.22 & 0.27 & 0.115 & 0.417 & 0.167 & 262518 & 64605.4 & 0.583 & 0.500 & 233999 & 57587.0 \\
\hline 6 & 66465 & 15933.6 & 0.23 & 0.28 & 0.118 & 0.417 & 0.167 & 244350 & 58577.8 & 0.583 & 0.500 & 217081 & 52040.5 \\
\hline 7 & 58003 & 12195.0 & 0.28 & 0.35 & 0.142 & 0.417 & 0.167 & 171166 & 35987.1 & 0.583 & 0.500 & 148556 & 31233.6 \\
\hline 8 & 27792 & 5312.3 & 0.26 & 0.33 & 0.135 & 0.417 & 0.167 & 88906 & 16994.0 & 0.583 & 0.500 & 77679 & 14847.9 \\
\hline
\end{tabular}

TABLE 5. Seasonal (1 June-30 September) consumption $(\hat{Q})$ of prey in weight (metric tons) by striped bass of ages 3-8 in coastal waters of northern Massachusetts. Standard errors (SE) and prpoprtional standard errors (PSE) are shown.

\begin{tabular}{|c|c|c|c|c|c|c|c|}
\hline Age & Statistic & Polychaetes & Molluscs & Crustaceans & Fish & Other & All Prey \\
\hline \multirow[t]{3}{*}{3} & $\hat{Q}$ & 13.5 & 0.6 & 84.5 & 269.7 & 0.3 & 368.6 \\
\hline & $S E$ & 8.23 & 0.31 & 22.25 & 66.49 & 0.31 & 83.48 \\
\hline & PSE & 0.61 & 0.51 & 0.26 & 0.25 & 1.03 & 0.23 \\
\hline \multirow[t]{3}{*}{4} & $\hat{Q}$ & 18.3 & 73.7 & 677.0 & 751.9 & & 1520.9 \\
\hline & $S E$ & 13.29 & 42.09 & 163.30 & 199.18 & & 308.96 \\
\hline & PSE & 0.72 & 0.57 & 0.24 & 0.26 & & 0.20 \\
\hline \multirow[t]{3}{*}{5} & $\hat{Q}$ & 6.2 & 11.3 & 459.5 & 527.4 & 4.2 & 1008.7 \\
\hline & $S E$ & 4.24 & 10.05 & 120.92 & 140.11 & 9.43 & 207.44 \\
\hline & PSE & 0.68 & 0.89 & 0.26 & 0.26 & 2.24 & 0.21 \\
\hline \multirow[t]{3}{*}{6} & $\hat{Q}$ & 4.6 & 5.1 & 401.5 & 707.8 & $<0.1$ & 1119.2 \\
\hline & $\widehat{S E}$ & 3.37 & 7.00 & 137.35 & 171.96 & 0.07 & 236.89 \\
\hline & PSE & 0.73 & 1.37 & 0.34 & 0.24 & 1.40 & 0.21 \\
\hline \multirow[t]{3}{*}{7} & $\hat{Q}$ & $<0.1$ & 17.0 & 486.2 & 441.3 & 7.4 & 952.0 \\
\hline & $S E$ & 0.04 & 25.44 & 165.71 & 164.86 & 9.99 & 185.16 \\
\hline & PSE & 1.33 & 1.50 & 0.34 & 0.37 & 1.35 & 0.19 \\
\hline \multirow[t]{3}{*}{8} & $\hat{Q}$ & 1.1 & 9.1 & 453.3 & 139.8 & 3.0 & 606.3 \\
\hline & $S E$ & 1.61 & 10.56 & 101.21 & 56.62 & 3.32 & 111.89 \\
\hline & PSE & 1.46 & 1.16 & 0.22 & 0.40 & 1.11 & 0.18 \\
\hline
\end{tabular}

important to striped bass when Atlantic menhaden were absent. Atlantic herring were important to age 3 striped bass during June-July only. These differences in consumption may be due, in part, to the temporal and spatial availability of prey to striped bass. High densities of lobsters and rock crabs are known to occur in the rocky and boulder-strewn areas that dominate northern Massachusetts coastlines (Bigford, 1979; MacKenzie and Moring,
1985; Chase et al., 2002). In regions where rocky areas are absent, these crustaceans comprise lower percentages of the diet of striped bass (Nelson et al, 2003). Juvenile Atlantic herring are abundant in the nearshore waters of the Gulf of Maine, including Massachusetts, during spring and early summer, but they move to deeper, offshore areas during summer and autumn (Stevenson and Scott, 2005); therefore, the near-absence of herring 
TABLE 6. Seasonal consumption of selected prey in weight ( $\hat{Q}$ in metric tons), mean weight $(g)$ of individual prey ( $\hat{\bar{w}}$ ), seasonal consumption in numbers $(\hat{P})$, and proportional standard errors (PSE). Standard errors are shown in parentheses.

\begin{tabular}{|c|c|c|c|c|c|c|c|c|c|c|}
\hline Age & Prey & & $\hat{Q}$ & $P S E_{Q}$ & & $\hat{\bar{w}}$ & $P S E_{w}$ & & $\hat{P}$ & $P S E_{P}$ \\
\hline \multirow[t]{4}{*}{3} & Am. Lobster & 0.8 & $(0.54)$ & 0.68 & 29.3 & (12.17) & 0.41 & $2.7 \times 10^{4}$ & $\left(2.16 \times 10^{4}\right)$ & 0.79 \\
\hline & Rock Crab & 31.7 & (8.86) & 0.28 & 5.1 & (1.38) & 0.27 & $6.2 \times 10^{6}$ & $\left(2.42 \times 10^{6}\right)$ & 0.39 \\
\hline & Atl. Herring & 43.8 & (15.30) & 0.35 & 5.0 & $(0.72)$ & 0.14 & $8.8 \times 10^{6}$ & $\left(3.31 \times 10^{6}\right)$ & 0.38 \\
\hline & Menhaden & 182.6 & (57.40) & 0.31 & 2.2 & $(0.13)$ & 0.06 & $8.3 \times 10^{7}$ & $\left(2.66 \times 10^{7}\right)$ & 0.32 \\
\hline \multirow[t]{4}{*}{4} & Am. Lobster & 100.5 & (38.60) & 0.38 & 29.3 & (12.17) & 0.41 & $3.4 \times 10^{6}$ & $\left(1.94 \times 10^{6}\right)$ & 0.57 \\
\hline & Rock Crab & 274.9 & (67.78) & 0.25 & 7.8 & $(0.47)$ & 0.06 & $3.5 \times 10^{7}$ & $\left(8.95 \times 10^{6}\right)$ & 0.25 \\
\hline & Atl. Herring & 20.4 & $(8.79)$ & 0.43 & 5.0 & $(0.72)$ & 0.02 & $4.1 \times 10^{6}$ & $\left(1.85 \times 10^{6}\right)$ & 0.45 \\
\hline & Menhaden & 597.5 & (179.4) & 0.30 & 2.1 & $(0.07)$ & 0.03 & $2.8 \times 10^{8}$ & $\left(8.61 \times 10^{7}\right)$ & 0.30 \\
\hline \multirow[t]{4}{*}{5} & Am. Lobster & 75.0 & (33.79) & 0.45 & 29.3 & (12.17) & 0.41 & $2.6 \times 10^{6}$ & $\left(1.57 \times 10^{6}\right)$ & 0.61 \\
\hline & Rock Crab & 227.4 & (72.63) & 0.32 & 9.8 & $(0.74)$ & 0.08 & $2.3 \times 10^{7}$ & $\left(7.62 \times 10^{6}\right)$ & 0.33 \\
\hline & Atl. Herring & - & & & & & & & & \\
\hline & Menhaden & 375.3 & (136.4) & 0.34 & 2.7 & $(0.10)$ & 0.04 & $1.4 \times 10^{8}$ & $\left(4.71 \times 10^{7}\right)$ & 0.34 \\
\hline \multirow[t]{4}{*}{6} & Am. Lobster & 38.6 & (29.79) & 0.77 & 29.3 & (12.17) & 0.41 & $1.3 \times 10^{6}$ & $\left(1.15 \times 10^{6}\right)$ & 0.88 \\
\hline & Rock Crab & 172.5 & (77.92) & 0.45 & 5.8 & $(0.71)$ & 0.12 & $3.0 \times 10^{7}$ & $\left(1.39 \times 10^{7}\right)$ & 0.47 \\
\hline & Atl. Herring & 35.4 & $(48.25)$ & 1.36 & 106.0 & (39.73) & 0.37 & $3.3 \times 10^{5}$ & $\left(4.72 \times 10^{5}\right)$ & 1.41 \\
\hline & Menhaden & 331.3 & (116.7) & 0.35 & 2.5 & $(0.15)$ & 0.06 & $1.3 \times 10^{8}$ & $\left(4.74 \times 10^{7}\right)$ & 0.36 \\
\hline \multirow[t]{4}{*}{7} & Am. Lobster & 232.8 & (109.9) & 0.47 & 79.7 & (14.81) & 0.18 & $2.9 \times 10^{6}$ & $\left(1.48 \times 10^{6}\right)$ & 0.51 \\
\hline & Rock Crab & 120.8 & (55.46) & 0.46 & 10.2 & (1.07) & 0.10 & $1.2 \times 10^{7}$ & $\left(5.58 \times 10^{6}\right)$ & 0.47 \\
\hline & Atl. Herring & 35.9 & (50.28) & 1.40 & 106.0 & (39.73) & 0.37 & $3.4 \times 10^{5}$ & $\left(4.91 \times 10^{5}\right)$ & 1.45 \\
\hline & Menhaden & 150.1 & (104.7) & 0.70 & 4.1 & $(0.20)$ & 0.05 & $3.7 \times 10^{7}$ & $\left(2.56 \times 10^{7}\right)$ & 0.70 \\
\hline \multirow[t]{4}{*}{8} & Am. Lobster & 192.8 & $(84.36)$ & 0.44 & 79.7 & (14.81) & 0.18 & $2.4 \times 10^{6}$ & $\left(1.15 \times 10^{6}\right)$ & 0.48 \\
\hline & Rock Crab & 160.2 & (70.38) & 0.44 & 11.1 & (1.31) & 0.12 & $1.4 \times 10^{7}$ & $\left(6.57 \times 10^{6}\right)$ & 0.45 \\
\hline & Atl. Herring & 35.0 & $(27.44)$ & 0.78 & 106.0 & (39.73) & 0.37 & $3.3 \times 10^{5}$ & $\left(2.87 \times 10^{5}\right)$ & 0.87 \\
\hline & Menhaden & - & & & - & & & - & & \\
\hline \multirow[t]{4}{*}{ All } & Am. Lobster & 640.5 & (150.7) & 0.24 & & & & $1.3 \times 10^{7}$ & $\left(3.33 \times 10^{6}\right)$ & 0.26 \\
\hline & Rock Crab & 987.5 & (155.1) & 0.16 & & & & $1.2 \times 10^{8}$ & $\left(2.03 \times 10^{7}\right)$ & 0.17 \\
\hline & Atl. Herring & 170.5 & (76.94) & 0.45 & & & & $1.4 \times 10^{7}$ & $\left(3.86 \times 10^{6}\right)$ & 0.28 \\
\hline & Menhaden & 1636.8 & (280.5) & 0.17 & & & & $6.8 \times 10^{8}$ & $\left(1.15 \times 10^{8}\right)$ & 0.17 \\
\hline
\end{tabular}

in the diets during August-September may reflect this migratory pattern. Atlantic menhaden young-of-the-year migrate from local estuaries to nearshore waters during August-September (Munroe 2002; Chase et al., 2002), and become more available to striped bass in nearshore waters. The importance of menhaden to the production of striped bass has been reported in other studies (Hartman and Brandt, 1995c; Uphoff, 2003).

Our results also showed that the contribution of specific prey to the production of striped bass varied with the age of striped bass. Rock crabs and lobsters became more important to striped bass as bass aged, but Atlantic menhaden became less important. The increase in rock crab and lobster importance may reflect increases in predator morphology related to ingestion (e.g. gape height and throat width) as bass grow in size (e.g. Chervinski et al., 1989; Hartman, 2000b). The decline in menhaden importance with age during August-September may reflect the absence of large, adult schools from nearshore waters in the past decade that seem to be optimal sizes for older (and larger) bass (Overton, 2002).

Seasonal growth conversion efficiencies of striped bass from northern Massachusetts were equal to or higher than annual growth conversion efficiencies of striped bass from Chesapeake Bass (Hartman and Brandt, 1995c). Although difficult to interpret because of the differences in the duration over which the conversion efficiencies were calculated, the results may suggest that bass foraging in 
TABLE 7. Comparison of striped bass consumption and fishery landings characteristics from northern Massachusetts in 2000. $95 \%$ confidence intervals are shown in parentheses.

\begin{tabular}{|c|c|c|c|c|}
\hline \multirow{2}{*}{$\begin{array}{l}\text { Prey } \\
\text { Am. Lobster }\end{array}$} & \multirow{2}{*}{$\frac{\text { Unit }}{\text { Biomass (t) }}$} & \multicolumn{2}{|c|}{$\begin{array}{l}\text { Striped Bass } \\
\text { Consumption }\end{array}$} & \multirow{2}{*}{$\begin{array}{r}\begin{array}{r}\text { Fishery } \\
\text { Landings }\end{array} \\
2253\end{array}$} \\
\hline & & 640.5 & (345.1-935.8) & \\
\hline & Number (millions) & 12.7 & $(3.3-19.2)$ & 3.9 \\
\hline & Mean Carapace Length (mm) & 36 & & 88 \\
\hline \multirow[t]{3}{*}{ Rock Crab } & Biomass (t) & 987.5 & $(683.5-1291.4)$ & 12.0 \\
\hline & Number (millions) & 120.7 & $(80.9-160.9)$ & $<0.1$ \\
\hline & Mean Carapace Width (mm) & 30 & & 140 \\
\hline \multirow[t]{3}{*}{ Atlantic Herring } & Biomass (t) & 170.5 & (31.4-309.5) & $4361^{1}$ \\
\hline & Number (millions) & 13.8 & (6.3-21.4) & 23.1 \\
\hline & Mean Total Length (mm) & 84 & & 280 \\
\hline \multirow[t]{3}{*}{ Menhaden } & Biomass (t) & 1636.8 & (1 096.2-2 177.4) & $136^{1}$ \\
\hline & Number (millions) & 675.6 & $(450.2-910.0)$ & 0.7 \\
\hline & Mean Total Length (mm) & 62 & & 242 \\
\hline
\end{tabular}

${ }^{1}$ represents landings from all Massachusetts waters

northern Massachusetts waters experience during their summer residence a slight growth advantage over resident Chesapeake Bay fish perhaps due to a larger scope for growth at more optimum temperatures and/or higher, consistent prey availability (Brandt, 1993). Our estimates of seasonal age-specific individual consumption for ages 3-6 represent about $21-30 \%$ of the annual individual consumption for resident striped bass of age 3-6 in Chesapeake Bay (Hartman and Brandt, 1995c).

\section{Estimates of Abundance}

The accuracy of the estimates of average abundance is entirely dependent on the mortality parameters and catch data included in the cohort survival-catch equation model. Many simplifications were made because of lack of data. A constant natural mortality rate was used for all ages because only one estimate is available (Anon., 2004), but in reality it is likely higher for the younger ages (Quinn and Deriso, 1999). Higher natural mortality rates would increase the estimates of average abundance produced in this study. The $2000 \mathrm{~F}$ estimate used is reasonable given that it is similar to the $2000 \mathrm{~F}$ estimate for the coast-wide striped bass population (Anon., 2004); however, average abundance estimates would change slightly if the full $F$ was distributed differently across months. If MRFSS data could be partitioned into finer spatial scales, boat catches from nearshore water could be incorporated into the model which would add harvest and release to the model, ultimately increasing the estimates of average abundance. Given current data limitation and knowledge of striped bass population and fishery dynamics, the abundance estimates are the best available for northern Massachusetts.

\section{Age-class and Population Consumption}

Striped bass appear to consume substantial amounts of prey during their seasonal residence in nearshore waters of northern Massachusetts. The striped bass population of ages 3-8 consumed over $5500 \mathrm{t}$ of prey (mostly crustaceans and fish) and, compared to the results of Hartman (2003), the estimate represents about $4 \%$ of the total consumption for the Atlantic coast striped bass population. Striped bass consumption of Atlantic menhaden and herring from northern Massachusetts in 2000 represented about $0.4 \%$ of the Atlantic coast abundance of ages 0 and 1 menhaden (Anon., 2003) and it represented about $0.3 \%$ of the Georges Bank/Gulf of Maine population of age 0 (back-calculated from age 1 recruitment in 2001 and $M=0.5$ ) and age 1 Atlantic herring (Overholtz et al., 2004). In 2000, age 4 striped bass, the large 1996 year-class from Chesapeake Bay, had the highest contribution to total biomass consumption suggesting that if striped bass are capable of exerting significant predation pressure on prey, it will vary, in part, with striped bass year-class strength. Similar conclusions have been reached for coastal bluefish (Buckel et al., 1999) and 
Chesapeake Bay resident striped bass (Hartman and Brandt, 1995c).

Striped bass could have local influence on population dynamics of rock crabs, menhaden, and lobsters in Massachusetts because striped bass consumption exceeded the statewide and regional fisheries landings in biomass and/or numbers for these species. However, the true strength of their impact will depend on the population sizes of the prey. If consumption of prey by striped bass reaches levels that impact prey abundances, the influence will be likely on recruitment of individuals to the local and coastal fisheries because striped bass consumed mostly pre-recruits (YOY and age 1). Given that striped bass abundance has increased dramatically since the late 1980s, their predatory impact has probably increased as well. Uphoff (2003) suggested that increased predation by the recovered striped bass population was responsible for declines in Atlantic menhaden population in Chesapeake Bay and possibly coast-wide. In Massachusetts, lobster recruitment to the inshore Gulf of Maine area has been declining (Anon., 2006) concurrent to increases in recreational catches (a reasonable proxy for striped bass abundance), suggesting potential impact by striped bass predation. Although cause and effect can not be insinuated from this comparison, it does suggest that further quantification of striped bass and prey population dynamics, particularly predation mortality, is warranted. Currently, there are no estimates of local prey abundances from which the direct impact of striped bass predation on prey could be quantified. This should be the next step in the investigations to understand the impacts of striped bass predation in Massachusetts.

\section{Acknowledgements}

Funding for this study was provided by the Sportfish Restoration Funds Grant F-57-R. We thank Micah Dean for producing Fig. 1, and Jeff Plouff and Michelle Ferrante for processing prey samples. Comments by Alexei Sharov, and two anonymous reviewers improved the quality of the manuscript. This is Massachusetts Division of Marine Fisheries Contribution No. 16.

\section{References}

ANON. 2003. Atlantic Menhaden 2003 Stock Assessment Report. Report to the Atlantic States Marine Fisheries Commission. 152 p.

2004. 2004 Stock Assessment Report for Striped Bass: Catch-at-Age Based VPA \& Tag Release/Recovery Based Survival Estimation. Report to the Atlantic States Marine Fisheries Commission (SBTC Report \#2004-4). $93 \mathrm{p}$.
2006. American Lobster Assessment for Peer Review. Report to the Atlantic States Marine Fisheries Commission, Stock Assessment Report 06-03.

BARTELL, S. M., J. E. BRECK, R. H. GARDNER, and A. L. BRENKERT. 1986. Individual parameter perturbation and error analysis of fish bioenergetics models. Can. J. Fish. Aquat. Sci., 43: 160-168.

BEAUCHAMP, D. A,., D. J. STEWART, and G. L. THOMAS. 1989. Corroboration of a bioenergetics model for sockeye salmon. Trans. Am. Fish. Soc., 118: 597-607.

BIGELOW, H. B., and W. C. SCHROEDER. 1953. Fishes of the Gulf of Maine. Fish Bull., 53: 577 p.

BIGFORD, T. E. 1979. Synopsis of biological data on the rock crab, Cancer irroratus Say. NOAA Tech. Rep. NMFS Circ., 426: 26 p.

BOWMAN, R. E. and W. MICHAELS. 1981. Food habits of seventeen species of northwest Atlantic fish. NOAA Tech. Memor., NMFS-F/NEC-28: 183 p.

BRANDT, S. B. 1993. The effects of thermal fronts on fish growth: a bioenergetic evaluation of food and temperature. Estuaries 16(1): 142-159.

BUCKEL, J. A., M. J. FOGARTY, and D. O. CONOVER. 1999. Mutual prey of fish and humans: a comparison of biomass consumed by bluefish, Pomatomus saltatrix, with that harvested by fisheries. Fish. Bull., 97: 776-785.

CHAPMAN, D. G. and D.S. ROBSON. 1960. The analysis of a catch curve. Biometrics, 16: 354-368.

CHASE, B. C. 2002. Differences in diet of Atlantic bluefin tuna (Thunnus thynnus) at five seasonal feeding grounds on the New England continental shelf. Fish. Bull., 100: $168-180$.

CHASE, B. C., J. PLOUFF, and W. CASTONGUAY. 2002. A study of the marine resources of Salem Sound, 1997. Massachusetts Division of Marine Fisheries Technical Report TR-6. 143 p.

CHERVINSKI, J. G. T. KLAR, and N. C. PARKER. 1989. Predation by striped bass and striped bass $\times$ white bass hybrids on redbelly tilapia and common carp. Prog. Fish Cultur., 51(2): 101-104.

DIODATI, P. J. and R. A. RICHARDS. 1996. Mortality of striped bass hooked and released in salt water. Trans. Am. Fish. Soc., 125: 300-307.

EFRON, B. and R. TIBSHIRANI. 1998. An Introduction to the Boostrap. Monographs on Statistics and Applied Probability 57. CRC Press LLC. Boca Raton, FL. 436 p.

ESTRELLA, B. T. and D. J. M'KIERNAN. 1989. Catch-perunit-effort and biological parameters from the Massachusetts coastal lobster (Homarus americanus) resource: description and trends. NOAA Tech. Rep. NMFS, 81: 21 p.

FIELD, J. D. 1997. Atlantic striped bass management: where did we go right? Fisheries, 22: 6-9.

FERRY, K. 2003 MS. Factors driving distribution of migratory striped bass across Massachusetts estuaries: predator-prey interactions and implications for multispecies management. Masters Thesis. University of Massachusetts, Amherst, MA.

HADDON,M.2001. ModellingandQuantitativeMethodsinFisheries. Chapman and Hall/CRC, Boca Raton, Florida, USA. $406 \mathrm{p}$. 
HANSON, P. C., T. B. JOHNSON, D. E. SCHINDLER, and J. F. KITCHELL. 1997. Fish Bioenergetics 3.0. University of Wisconsin Sea Grant Institute, Madison, Wisconsin.

HARTMAN, K. J. 2000a. Variability in daily ration estimates of age-0 striped bass in the Chesapeake Bay. Trans. Am. Fish. Soc., 129: 1181-1186.

2000b. The influence of size on striped bass foraging. Mar. Ecol. Prog. Ser., 194: 263-268.

HARTMAN, K. J. and S. B. BRANDT. 1993. Systematic sources of bias in a bioenergetics model: examples for age-0 striped bass. Trans. Am. Fish. Soc., 122: 912-926.

HARTMAN, K. J. and S. B. BRANDT. 1995a. Comparative energetics and the development of bioenergetics models for sympatric estuarine piscivores. Can. J. Fish. Aquat. Sci., 52: 1647-1666.

1995b. Estimating energy density of fish. Trans. Am. Fish. Soc., 124: 347-355.

1995c. Predatory demand and impact of striped bass, bluefish, and weakfish in the Chesapeake Bay: applications of bioenergetic models. Can. J. Fish. Aquat. Sci., 52: 1667-1687.

HARTMAN, K. J. 2003. Population-level consumption by Atlantic coastal striped bass and the influence of population recovery upon prey communities. Fish. Manage. Ecol., 10: $281-288$.

HUUSKONEN, H., J. KARJALAINEN, N. MEDGYESY, and W. WEISER. 1998. Energy allocation in larval and juvenile Coregonus lavaretus: validation of a bioenergetics model. J. Fish. Biol., 52(5): 962-972.

KITCHELL, J. F., D. J. STEWART, and D. WEININGER. 1977. Application of a bioenergetics model to yellow perch (Perca flavescens) and walleye (Stizostedion vitreum vitreum). J. Fish. Res. Board. Can., 34: 1922-1935.

MacKENZIE, C. and J. R. MORING. 1986. Species profiles: life histories and environmental requirements of coastal fishes and invertebrates (North Atlantic) - American lobster. U. S. Fish Wildl. Serv. Biol. Rep., 82(11.33). U. S. Army Corps of Engineers, TR EL-82-4. 19 p.

MOOD, A. M., F. A. GRAYBILL and D. C. BOES. 1974. Introduction to the Theory of Statistics. McGraw-Hill Press, Third Edition. 564 p.

MUNROE, T. 2002. Atlantic Menhaden. In: Bigelow and Schroeder's Fishes of the Gulf of Maine, Smithsonian Institute, B. B. Collette and G. Klein-MacPhee (eds.), p.133-141.

NELSON, G. A, M. P. ARMSTRONG, and T. HOOPES. 2001. 2000 Massachusetts Striped Bass Monitoring Report. Massachusetts Division of Marine Fisheries Technical Report TR-4, 13 p.

NELSON, G. A., B. C. CHASE, and J. STOCKWELL. 2003. Food habits of striped bass (Morone saxatilis) in coastal waters of Massachusetts. J. Northw. Atl. Fish. Sci.,
32: $1-25$.

OVERHOLTZ, W.J., L. D. JACOBSON, G. D. MELVIN, M. CIERI, M. POWER, D. LIBBY and K. CLARK. 2004. Stock assessment of the Gulf of Maine-Georges Bank herring complex, 2003. Northeast Fisheries Science Center Reference Document 04-06: 290 p.

OVERTON, A. S. 2002. Striped bass predator-prey interactions in Chesapeake Bay and along the Atlantic coast. Ph.D. diss., Univ. Maryland Eastern Shore, Princess Anne, MD, $226 \mathrm{p}$.

PEROS, D. On the water magazine, January 1999. On the Water LLC, 50 Depot Avenue, Falmouth, MA 02540.

POWER, K. D., and R. G. BROWN. 1987. Seabirds. In Georges Bank. R. H. Backus and P. W. Bourne (eds.). MIT Press, Cambridge, Mass.

PREIDE, I. G. 1985. Metabolic scope in fishes. In: Fish Energetics: New Perspectives. P. Tytler and P. Calow (eds.). The John Hopkins University Press, Baltimore, Maryland.

RICKER, W. E. 1975. Computation and interpretation of biological statistics of fish populations. Bull. Fish. Res. Board Can., 191: 382 p.

QUINN, T. J. and R. B.. DERISO. 1999. Quantitative Fish Dynamics. Oxford University Press, New York, NY. 542 p.

RICHARDS, R. A. and P. J. RAGO. 1999. A case history of effective fishery management: Chesapeake Bay striped bass. N. Amer. J. Fish. Manage., 19: 356-375.

SAS INSTITUTE. 2000. SAS OnlineDoc, version 8. SAS Institute Inc., Cary, NC. http://ww.sas.com/ts.

SETZLER, E. M., W. R. BOYNTON, K. V. WOOD, H. H. ZION, L. LUBBERS, N. M. MOUNTFORD, P. FRERE, L. TUCKER, and J. A. MIHURSKY. 1980. Synopsis of biological data on striped bass, Morone saxatilis (Walbaum). NOAA Tech. Rep. NMFS Circ., 433: 69 p.

STEIMLE, F. W. and R. J. TERRANOVA. 1985. Energy equivalents of marine organisms from the continental shelf of the temperate northwest Atlantic. J. Northw. Atl. Fish. Sci., 6: 117-124.

STEVENSON, D. K. and M. L. SCOTT. 2005. Essential fish habitat document: Atlantic herring, Clupea harengus, life history and habitat characteristics, second edition. NOAA Tech. Mem. NMFS-NE-192, 84 p.

THAYER, G. W., W. E. SCHAAF, J. W. ANGELOVIC and. M. W. LaCROIX. 1973. Caloric measurements of some estuarine organisms. Fish. Bull., 71: 289-296.

UPHOFF, J. H., Jr. 2003. Predator-prey analysis of striped bass and Atlantic menhaden in upper Chesapeake Bay. Fish. Manage. Ecol., 10: 313-322.

WIGLEY, S. E., H. M. McBRIDE, and N. J. MHUGH. 2003. Length-weight relationships for 74 fish species collected during NEFSC research vessel bottom trawl surveys, 1992-99. NOAA Tech. Mem. NMFS-NE-171. 